\title{
Recommendations of the European Advisory Committee of Cytotechnology and European Federation of Cytology Societies for Training and Education of Cytotechnologists in Europe
}

\author{
Veronika Anic $^{\mathrm{a}}$ Maj Liv Eide ${ }^{\mathrm{b}}$ Beatrix Cochand-Priollet ${ }^{c}$ \\ Danijela Vrdoljak Mozetic ${ }^{d}$ Giovanni Negrie ${ }^{\text {Philippe Vielh }}{ }^{f}$ \\ aDepartment of Clinical Cytology and Cytogenetics, Merkur University Hospital, Zagreb, Croatia; ${ }^{\circ}$ Department of \\ Pathology, Trondheim University Hospital and Department of Biomedical Laboratory Science, Faculty of Natural \\ Sciences, Norwegian University of Science and Technology, NTNU, Trondheim, Norway; 'Department of Pathology, \\ Cochin Hospital, University Paris, Paris, France; ${ }^{\mathrm{d} D e p a r t m e n t}$ of Pathology and Cytology, Clinical Hospital Centre \\ Rijeka, Department of Pathology, Faculty of Medicine, University of Rijeka, Rijeka, Croatia; 'Department of \\ Pathology, Central Hospital Bolzano, Bolzano, Italy; ${ }^{f}$ Medipath and American Hospital of Paris, Paris, France
}

\section{Keywords}

Cytotechnologists - Education - Europe - European Advisory Committee of Cytotechnology - European Federation of Cytology Societies

\begin{abstract}
Background: Faced with changes in cytodiagnostics, cervical cancer screening programs, the introduction and application of new methods, the cytotechnological educational program requires the necessary changes and additions. Insufficient, uneven as well as inaccessible education of cytotechnologists in European countries was the basis for making these recommendations. Summary: The results of previous research and publications related to the currently available education of cytotechnologists in Europe, the needs and suggestions were given by the European Advisory Committee of Cytotechnology (EACC) and European Federation of Cytology Societies (EFCS) for optimal education of future generations of cytotechnologists were used in the preparation of these recommendations. The EACC and EFCS propose a 1-year education and training program divided into 3 modules: gynecological,
\end{abstract}

nongynecological exfoliative, and fine-needle aspiration cytology. Training programs should be organized by an accredited university, preferably a combination of internal education in a cytology laboratory and theoretical education at the university. Cytopathologists and cytotechnologists with at least 5 years of work experience in cytodiagnostics should participate in education. Upon completion of the training program, the EACC and EFCS propose an official name: EFCS certified cytotechnologist. Key Messages: The EACC and EFCS believe that it is extremely important that these recommendations are recognized and implemented by institutions that provide education for cytotechnologists so that they can meet the growing requirements of the profession with their acquired knowledge and competencies.

(c) 2021 S. Karger AG, Basel

\section{Introduction}

The training and education of cytotechnologists in European countries varies greatly in terms of qualifications, methods, quality, level of education, and the recognition karger@karger.com

(c) 2021 S. Karger AG, Basel

www.karger.com/acy

Karger ${ }^{\prime \prime}=$
Correspondence to:

Veronika Anic, veronika.anic1@gmail.com 
of the profession. The aim of these recommendations is not to impose, but to guide and assist national cytological and cytotechnological societies in drafting, amending, and supplementing the basic education program for cytotechnologists. It is important to harmonize the education and training of cytotechnologists in European countries, and there is an urgent need to develop and adapt these so as to meet the paradigm shift in cervical screening programs and the future needs in cytopathological diagnostics. We strongly believe that these guidelines will be helpful in the training and education of cytotechnologists. On a daily basis, they are confronted with the fact that, besides a good knowledge of morphology, they also need to be familiar with a growing range of new tests such as HPV-testing in screening programs against cervical cancer, automated screening, liquid-based cytology, new diagnostic methods and technologies including molecular and cytogenetic methods that are contributing to a more accurate diagnosis. Cytotechnologists must maintain the existing position in cytopathology diagnostics and be able to perform, understand, and correlate morphological findings with the findings of other relevant diagnostic methods. Proper training and education for the future needs in cytopathological diagnostics, especially in nongynecological cytology for the purpose of prescreening is a necessity, both for keeping the cytotechnologists in the laboratory as the number of cervical specimens will decrease substantially in a few years, as well as for the future of cytology in general.

\section{Material and Methods}

In 2010, the European Federation of Cytology Societies (EFCS), represented by the General Secretary Philippe Vielh, gave the assignment to draft guidelines for minimum requirements for practising Cytotechnology in Europe to members of the European Advisory Committee of Cytotechnology (EACC). An EACC Working Group, chaired by Veronika Anic and cochaired by Maj Liv Eide - on behalf of the EACC members was established. During 2019, the EFCS accepted the proposal of the EACC Working Group to develop a joint proposal for the education of cytotechnologists in European countries. The EACC/EFCS Working Group was expanded with new members: Beatrix Cochand - Priollet as a Secretary-General of the EFCS, Danijela VrdoljakMozetic as a Chairperson of the EFCS Educational Committee, Giovanni Negri from EFCS Tutorial Committee and Philippe Vielh as a former EFCS General Secretary, and the initiator of this document. On this occasion, this joint educational proposal was made.

Data were collected from the previous surveys and presentations delivered during the European Congresses of Cytology (ECC) of EFCS and during the International Congresses of Cytology (ICC) of the International Academy of Cytology regarding training and education of cytotechnologists:
- Training of cytotechnologists in Europe, from 2006 (EFCS/Eurocytology project)

- Preliminary report - basic requirements for practising cytotechnology in Europe, from 2010 (17th ICC, Edinburgh, Scotland)

- Training and education of cytotechnologists in Europe, from 2011 (36th ECC - Istanbul, Turkey)

- Minimum requirements for practising cytotechnology in Europe, from 2012 (37th ECC - Cavtat, Croatia)

- EACC recommendations for minimum requirements for practising cytotechnology in Europe, from 2013 (18th ICC - Paris, France)

- EACC recommendations for training and education of cytotechnologists in Europe, from 2015 (39th ECC - Milan, Italy)

- EACC training and education recommendations, from 2016 (40th ECC - Liverpool, England)

- Reality knocks at the door - do we need recommendations for education of Cytotechnologists in European countries from 2018 (41st ECC Madrid, Spain)

Data were also collected from articles related to this subject published in Cytopathology [1-3], articles from the American Society of Cytopathology $[4,5]$, and data provided by the European National Cytological and Cytotechnological Societies. All data collected, taking into account the needs and opportunities acceptable to all participating European countries, form the basis of this common conclusion on the basic requirements and guidelines for future education of cytotechnologists in Europe.

\section{Results}

\section{Basic Education before Entry into Cytotechnology Training}

In most of the countries who responded to the survey in 2010 and 2011, the basic educational requirement for entering into cytotechnology training was medical laboratory technology or bachelor's degree in biomedical science. The authors suggest that the basic educational standard required for entering into cytotechnology training should be a bachelor's degree (180 ECTS) in medical laboratory technology, biomedical science, or other medical profiles that are at college/university level where the educational level meets the criteria for entry into further training in cytotechnology. The subjects in the bachelor's program should encompass cell biology, biochemistry, anatomy, basic pathology, histology, molecular biology, laboratory technology methods, molecular diagnostics, and, preferably, an introduction to cytology. An introduction to cytology in the bachelor's program would be an advantage for recruiting students to the profession and with this background the training period in cytotechnology could be more efficient. Future cytotechnologists have to be multiskilled in order to meet the future needs and a bachelor's degree with the 
Table 1. Module A: gynecological cytology

\begin{tabular}{|c|c|c|}
\hline Subject & Knowledge & Skills \\
\hline $\begin{array}{l}\text { 1. Genital anatomy, physiology, and } \\
\text { histology }\end{array}$ & $\begin{array}{l}\text { Acquire knowledge about genital anatomy, } \\
\text { physiology, and histology }\end{array}$ & $\begin{array}{l}\text { Be able to know which cells are normally present, and } \\
\text { the implication of physiology }\end{array}$ \\
\hline 2. Basic clinical knowledge & $\begin{array}{l}\text { Knowledge of different medical terms and clinical } \\
\text { implications }\end{array}$ & Can gather relevant clinical information \\
\hline 3. Terminology & $\begin{array}{l}\text { Acquire knowledge of current and former } \\
\text { nomenclature in cervical cytology and histology }\end{array}$ & $\begin{array}{l}\text { Know the morphologic criteria for different cytological } \\
\text { and histological diagnosis }\end{array}$ \\
\hline $\begin{array}{l}\text { 4. Sample taking procedures of cervix, } \\
\text { ovary, vagina, endometrium, and vulva } \\
\text { for cytology and additional diagnostic } \\
\text { methods }\end{array}$ & $\begin{array}{l}\text { Know how to take a sample from the female } \\
\text { genitalia for cytology and additional diagnostic } \\
\text { methods. Know the difference between sample } \\
\text { taking of a conventional Pap smear and liquid- } \\
\text { based cervical cytology specimen }\end{array}$ & $\begin{array}{l}\text { Be able to take samples and advise sample-takers on } \\
\text { how to perform the procedures in case of inadequate } \\
\text { smears or on request }\end{array}$ \\
\hline $\begin{array}{l}\text { 5. Preparation and staining of cervical } \\
\text { specimens }\end{array}$ & $\begin{array}{l}\text { Knowledge of the performance of the different } \\
\text { steps in preparation and staining procedure }\end{array}$ & $\begin{array}{l}\text { Be able to assess adequate performance of preparation, } \\
\text { staining, and troubleshoot when suboptimal }\end{array}$ \\
\hline
\end{tabular}

6. Screening and interpretation of conventional and/or liquid-based cervical cytology specimens Specimen adequacy, cellular components Knowledge of factors that impair cervical cytology within normal limits, nonneoplastic findings, epithelial squamous and glandular abnormalities, and other epithelial and nonepithelial malignant neoplasms including extrauterine neoplasms

\section{specimens, and knowledge how to evaluate} specimen adequacy, cellular components within normal limits, cellular changes associated with inflammation and infections/organisms, effects of therapy, devices, and instrumentation. Knowledge of cellular features of different squamous and glandular abnormalities and other epithelial and nonepithelial malignant neoplasms including extrauterine neoplasms
Be able to microscopically assess technical quality, minimum number of epithelial cells, and recognize inadequate and normal specimens. Be able to microscopically identify different epithelial and nonepithelial cells in negative specimens, cellular changes due to inflammation and infections/ organisms, effects of therapy, devices, and instrumentation. Be able to microscopically identify and discriminate between borderline changes, premalignant, and malignant squamous and glandular lesions, and other epithelial and nonepithelial malignant neoplasms including extrauterine neoplasms

Be able to microscopically detect, select, and mark the cells most representative of a pathological process and suggest a diagnosis based on cytological criteria cells most representative of a pathological proces if present

\begin{tabular}{ll} 
7. Interpretation and diagnosis suggestion & $\begin{array}{l}\text { Knowledge of how to detect, select, and mark the } \\
\text { cells most representative of a pathological process } \\
\text { if present }\end{array}$ \\
\hline
\end{tabular}

8. Report Recognize and know how to report an inadequate or normal specimen

Be able to report and sign out inadequate or normal specimens

9. HPV-testing, immunocytochemistry, and other ancillary techniques

Knowledge of the principle of different commercial HPV-testing methods, immunocytochemistry, and other ancillary techniques, and their use in cervical screening programs

General subjects

10. Microscope Acquire knowledge of use and maintenance of a light microscope and screening techniques
Be able to perform HPV-testing methods, immunocytochemistry, or other ancillary techniques if the task is given and recognize and troubleshoot suboptimal results
Be able to utilize the microscope to properly visualize the specimen and screen specimens with a systematic screening technique

Be able to perform relevant prescreening or rescreening methods and techniques. Know where to find and how to use QA documents

Be able to use a computer for gathering patient information, reporting, and continuing education telecytology
11. Quality control and quality assurance procedures and documents

12. Basic informatics, telecytology
Knowledge of different prescreening and rescreening methods and techniques. Knowledge of QA official documents

Knowledge of how to use computers and electronic learning platforms on the internet

\section{proposed subjects would be a prerequisite. In a future with uncertainty about the cytotechnologist's place in diagnostic cytopathology, this issue needs serious and urgent attention.}

\section{Training in Cytotechnology}

After completing a bachelor's degree, we suggest that additional education in cytotechnology should be organized in the form of a 1-year postgraduate training 
Table 2. Module B: nongynaecological exfoliative cytology

\begin{tabular}{ll}
\hline Subject & Knowledge \\
\hline $\begin{array}{l}\text { 1. Anatomy, physiology, and histology of } \\
\text { urinary tract, respiratory tract, pleura, } \\
\text { peritoneum, pericard, CNS, joint, and }\end{array}$ & $\begin{array}{l}\text { Knowledge about anatomy, physiology, and histology of } \\
\text { urinary tract, respiratory tract, pleura, peritoneum, pericard, }\end{array} \quad \begin{array}{l}\text { BNS, joint, and alimentary tract } \\
\text { present and the implication of physiology }\end{array}$
\end{tabular}

alimentary tract

\begin{tabular}{ll}
\hline 2. Basic clinical knowledge & $\begin{array}{l}\text { Knowledge of different medical terms and clinical } \\
\text { implications }\end{array}$ \\
\hline $\begin{array}{l}\text { 3. Sample taking and assisting during } \\
\text { aspiration of nongyne exfoliative cytology }\end{array}$ & $\begin{array}{l}\text { Knowledge of sample taking procedures of different nongyne } \\
\text { exfoliative cytology specimens and their impact on } \\
\text { morphology, including knowledge of taking samples for a } \\
\text { diagnostic methods }\end{array}$ \\
$\begin{array}{l}\text { wide range of additional diagnostic methods (flow } \\
\text { cytometry, PCR, immunocytochemistry, cytochemistry, } \\
\text { cytogenetics, microbiology, etc.) }\end{array}$
\end{tabular}

4. Preparation and different staining
methods of non-gyne exfoliative cytology
specimens

5. Microscope
Knowledge of the performance of the different steps in preparation (cytocentrifuge, liquid-based cytology) and staining procedures

Acquire knowledge of use and maintenance of a light microscope and screening techniques

Can gather relevant clinical information

Be able to assist during aspirations/sample taking and advise sample-takers on how to perform the procedure in case of inadequate smears or on request

Be able to assess adequate performance of preparation, staining, and troubleshoot when suboptimal

Be able to utilize the microscope to properly visualize the specimen and screen specimens with a systematic screening technique

Knowledge of the principle of different ancillary techniques

Be able to perform ancillary techniques if 1 or more tasks are given, and recognize and troubleshoot suboptimal results immunocytochemistry, flow cytometry, molecular analysis, etc.)

and their use in diagnostics
7. Prescreening and interpretation of nongyne exfoliative cytology specimens

Specimen adequacy, cellular components Knowledge of specimen adequacy for different organs and within normal limits, nonneoplastic findings, cellular features of benign lesions, suspicious and malignant neoplasms, and metastasis collection methods. Knowledge of which normal cells are present in different organs and body sites, benign cellular changes associated with inflammation, effects of therapy, and instrumentation, suspicious and malignant neoplasms, and cellular features of metastasis in different organs
Be able to microscopically assess technical quality and representability of cellular specimens from different organs. Can microscopically assess if present cells are within normal limits and if cellular changes are associated with inflammation and infections/organisms, effects of therapy, and instrumentation. Be able to microscopically assess cellular features of different benign, suspicious, and malignant neoplasms. Can microscopically assess cellular features of metastasis in different organs

Be able to microscopically detect, select and mark the cells most representative of a pathological process and suggest a diagnosis based on cytological criteria program (60 ECTS) in cytotechnology divided into 3 modules: module A: gynecologic cytology, duration 12 months, module B: nongynecologic exfoliative cytology, duration 6 months, and module C: nongynecological fine-needle aspiration cytology, duration 6 months, which means that trainings in gynecologic and nongynecologic cytology are combined and learned in parallel. Training programs should be organized by an accredited university. The training should, preferably, be a combination of in-house training in a cytology laboratory, and education courses at the university. The curriculum for the postgraduate training programs for cytotechnologists should include specific subjects, with defined knowledge and skills in anatomy, physiology, histology and cytology of organs and tissues, theoretical and practical training in gynecologic cytology (Table 1), nongynecologic exfoliative cytology (Table 2), and nongynecologic fine-needle aspiration cytology (FNAC) (Table 3). The training program should also include ancillary techniques, quality assurance, quality control, and basics of informatics. The supervisors/teachers should be cytopathologists and cytotechnologists with minimum of 5 years of experience in 
Table 3. Module C: nongynecologic fine-needle aspiration cytology

\begin{tabular}{|c|c|c|}
\hline Subject & Knowledge & Skills \\
\hline $\begin{array}{l}\text { 1. Anatomy, histology, and physiology of } \\
\text { salivary gland, head and neck, thyroid, } \\
\text { lymph node, breast, soft tissue, spleen, } \\
\text { kidney, liver, pancreas, bone marrow, and } \\
\text { peripheral blood }\end{array}$ & $\begin{array}{l}\text { Knowledge of anatomy, histology, and physiology } \\
\text { of salivary gland, head and neck, thyroid, lymph } \\
\text { node, breast, soft tissue, spleen, kidney, liver, } \\
\text { pancreas, bone marrow, and peripheral blood }\end{array}$ & $\begin{array}{l}\text { Be able to recognize which cells are normally present } \\
\text { and the implication of physiology }\end{array}$ \\
\hline 2. Basic clinical knowledge & $\begin{array}{l}\text { Knowledge of different medical terms and clinical } \\
\text { implications }\end{array}$ & Can gather relevant clinical information \\
\hline $\begin{array}{l}\text { 3. Assisting during aspiration of nongyne } \\
\text { FNAC, sample taking for cytology and } \\
\text { additional diagnostic methods (flow } \\
\text { cytometry, cytogenetics, molecular } \\
\text { analysis, etc.) }\end{array}$ & $\begin{array}{l}\text { Knowledge of principles of FNAC performance } \\
\text { including image-guided FNAC like US, EBUS, } \\
\text { EUS, ERCP, CT, and stereotactic. Knowledge of } \\
\text { rapid on-site evaluation (ROSE) of adequacy of } \\
\text { FNAC and knowledge of how to communicate } \\
\text { results }\end{array}$ & $\begin{array}{l}\text { Be able to assist and take samples during aspirations } \\
\text { and advise sample-takers on how to perform the } \\
\text { procedures in case of inadequate smears or on request } \\
\text { Be able to microscopically assess on-site adequacy of } \\
\text { FNAC (ROSE) and communicate results of this } \\
\text { assessment }\end{array}$ \\
\hline $\begin{array}{l}\text { 4. Slide preparation and different staining } \\
\text { methods of FNAC specimens }\end{array}$ & $\begin{array}{l}\text { Knowledge of the performance of the different } \\
\text { steps in preparation and staining procedures incl. } \\
\text { rapid staining }\end{array}$ & $\begin{array}{l}\text { Be able to assess adequate performance of preparation } \\
\text { and staining, and troubleshoot when suboptimal }\end{array}$ \\
\hline $\begin{array}{l}\text { 5. Ancillary techniques like cytochemistry, } \\
\text { immunocytochemistry, flowcytometry, } \\
\text { cytogenetics, molecular analysis, etc. }\end{array}$ & $\begin{array}{l}\text { Knowledge of the principle of different ancillary } \\
\text { techniques and their use in diagnostics }\end{array}$ & $\begin{array}{l}\text { Be able to perform ancillary techniques if } 1 \text { or more } \\
\text { tasks are given and recognize and troubleshoot } \\
\text { suboptimal results }\end{array}$ \\
\hline \multicolumn{3}{|c|}{ 6. Prescreening and interpretation of nongyne FNAC specimens } \\
\hline $\begin{array}{l}\text { Specimen adequacy, cellular components } \\
\text { within normal limits, nonneoplastic } \\
\text { findings, cellular features of benign } \\
\text { lesions, suspicious and malignant } \\
\text { neoplasms, and metastasis }\end{array}$ & $\begin{array}{l}\text { Knowledge of specimen adequacy for different } \\
\text { organs, and collection methods. Knowledge of } \\
\text { which normal cells are present in different organs } \\
\text { and body sites. Knowledge of cellular changes } \\
\text { associated with inflammation, effects of therapy, } \\
\text { and instrumentation, benign and suspicious } \\
\text { conditions, malignant neoplasms, and cellular } \\
\text { features of metastasis in different organs }\end{array}$ & $\begin{array}{l}\text { Be able to microscopically assess technical quality and } \\
\text { representability of cellular specimens from different } \\
\text { organs. Can microscopically assess if cells present are } \\
\text { within normal limits and if cellular changes are } \\
\text { associated with inflammation and infections/ } \\
\text { organisms, effects of therapy, and instrumentation. Be } \\
\text { able to microscopically assess cellular features of } \\
\text { different benign, suspicious, and malignant neoplasms. } \\
\text { Can microscopically assess cellular features of } \\
\text { metastasis in different organs }\end{array}$ \\
\hline 7. Interpretation and diagnosis suggestion & $\begin{array}{l}\text { Knowledge of how to detect, select, and mark the } \\
\text { cells most representative of a pathological process } \\
\text { if present }\end{array}$ & $\begin{array}{l}\text { Be able to microscopically detect, select, and mark the } \\
\text { cells most representative of a pathological process and } \\
\text { suggest a diagnosis based on cytological criteria }\end{array}$ \\
\hline
\end{tabular}

practising cytopathology and cytotechnology. The trainee should have access to teaching slide collections with a variety of slides from different organs and body sites, with various staining methods and ancillary techniques, covering nonmalignant, inflammatory, premalignant, and malignant diagnosis. The trainee should keep a record of training activities in a portfolio, which should be regularly assessed by a supervisor. For obtaining EFCS Cytotechnology degree, the Universities should seek the approval of the cytotechnology course program from EFCS. At the end of each module, the level of competence should be tested with an exam. After completion of all 3 training modules and a successful final examination, EFCS and EACC propose that the cytotechnologist receive a national university diploma with an official title: EFCS certified cytotechnologist. For those who wish to obtain a master's degree, we suggest an additional education at the university working toward a relevant master's thesis, but this would be optional. EFCS diploma in cytotechnology is suitable for laboratory management, training, teaching, and research. Given the diversity and absence of European standards in the education of Cytotechnologists, it is recommended that, after completing the training, cytotechnologists can verify their acquired knowledge through a National exam, through QUATE (Quality Assurance, Training, and Examinations committee) Aptitude Test in cervical cytology or International Academy of Cytology comprehensive cytotechnology examination, depending on relevant national or local regulations. 


\section{Continuing Education and External Quality}

Assurance Program

Cytotechnologists should participate in discussions and reviews of difficult cases with cytopathologists. They should participate in training courses, tutorials, and professional development courses on new techniques and developments, have access to cytology journals and textbooks, and participate at national and international cytology meetings and congresses. They should also participate in external quality assurance programs where available.

\section{Conclusion}

Major changes will happen in the cervical screening programs in the next few years, due to HPV vaccination and HPV primary screening. Now is the time to make an effort to agree on minimum requirements for practising cytotechnology in Europe. It is extremely important that these recommendations, especially for nongynecological cytology, become a guiding principle in the education of cytotechnologists in Europe. The curriculum is not very different from the one that the American Society of Cytopathology, American Society of Cytotechnology, and other societies approved in 2013 $[4,5]$. EACC and EFCS as professional Societies are the only competent bodies to draw up guidelines for training and education of cytotechnologists in Europe. The authors of these recommendations believe that it is important to spread the word about EACC and EFCS attitudes toward the future training and education of cytotechnologists. We are aware that these recommendations mainly apply to those countries that have well-organized cytology settings, to those who will be trained and employed in the future, but also provide a good professional instruction to those societies that do not yet have a program/have incomplete educational program for cytotechnologists in their countries. Cytotechnologists possess a unique combination of morphological, medical laboratory, and technological knowledge; hence, it would be a loss for the cytology and pathology departments if the cytotechnologists lost their positions.

\section{Statement of Ethics}

The authors have no ethical conflicts to disclose.

\section{Conflict of Interest Statement}

The authors have no conflicts of interest to declare.

\section{Funding Sources}

The authors have no funding to report.

\section{Author Contributions}

Veronika Anic and Maj Liv Eide writing and design of the original draft, review and editing, and creation of tables. Beatrix Cochand-Priollet, Danijela Vrdoljak-Mozetic, Giovanni Negri, and Philippe Vielh provided critical comments. All the authors contributed to the editing and proofreading of the final manuscript for submission.

\section{References}

1 Anic V, Eide ML. Survey of training and education of cytotechnologists in Europe. Cytopathology. 2014;25(5):302-6.

2 Herbert A, Anic V, Cochand-Priollet B, Dina $\mathrm{R}$, Ehya $\mathrm{H}$, Eide ML, et al. Training and practice of cytotechnologists: a discussion forum focused on Europe. Cytopathology. 2014; 25(5):307-15.
3 Herbert A, Cochand-Priollet B, Cross P, Desai M, Dina R, Duskova J, et al. Survey of medical training in cytopathology carried out by the journal Cytopathology. Cytopathology. 2010;21:147-56.
4 A white paper: Facing the Future of Cytopathology: Discerning the Future Needs of our Profession. American Society of Cytopathology 2010. http://www.cytopathology.org/ website/download.asp?id=3439 Accessed 2014 Jul 6.

5 Standards and Guidelines for the Accreditation of Educational Programs in Cytotechnology, October 2013. https://www.ascp.org/ content/home. 